\title{
Assessment of the environmental value of the Zichy Castle Park in Voivodeni, Romania - Brief description
}

\author{
Lóránt KOVÁCS ${ }^{1}$ \\ ${ }^{1}$ Department of Horticulture, Faculty of Technical and Human Sciences, \\ Sapientia University, Sighişoarei 1/C, Târgu Mureş, Romania, \\ kovacs_lorant@yahoo.com
}

Manuscript received 27. 08. 2014; revised 04. 09. 2014; accepted 14. 09. 2014

\begin{abstract}
The Zichy Castle from Vajdaszentivány (Voievodeni) is located in Mureş County, central Romania, south-west from the town of Reghin. Its construction in classical baroque style dates back to the beginning of the XVIII century. The archaeological findings from the area show that Vajdaszentivány was already populated in the Copper Age. The findings of gray dishes from the III and IV centuries were considered by Dr. Protase as indigenous Daco-Roman relics. The Roman presence here was demonstrated by residues of the hewn-stone road along the Maros River. After the Roman Age, several other populations (Goths, Slavonic peoples, Darghins and Huns) settled down here. The feudal Hungarian state occupied this area around the XI century. Several streams, terraces and old cemetery ruins demonstrate that the Hungarians used the region for protective purposes. The first written records of Vajdaszentivány date back to 1332, when the Papal documents (Sacerdos de Sancto Johanne) mention the settlement for the first time. In 1366, the name of the village was Márton-Szent-Iván, and during the centuries it belonged to several old and noble families and dynasties as szentiváni Székely, monoszlai Losonczi, Szakácsi, the Bánffy and Dezsőfi, the Szentiváni, Butkai, Balog, Kecseti, Kerelői, Szengyeli, Dengelegi, Fodor, vajdaszentiványi Földvári, Kóka, Piski, Járai or Járai Felsőjárai Abafája. During the first half of the $19^{\text {th }}$ century, among former Hungarians noble owners of the village, the following can be mentioned: Count Sámuel Kemény, Albert Horváth, Budai, Szőcs (Károly és Mihály) and Duke Löwenthál. Later on, the village of Vajdaszentivány became famous because of its castle, later named the "Zichy Castle," but also because of its citizens as preservers of folk music, folk dance and folk tales.
\end{abstract}

Keywords: cultural value, castles, historical value, rehabilitation 


\section{The brief history of the castle}

The single-storeyed building was originally owned by the Order of Friars Minor, after which the members of the Kemény Family became the owners of the estate. The foreign-educated Sámuel Kemény I, after his return, married Kata Bethlen, and became one of the political leaders of Transylvania in the XVI century. The first restoration works on the castle were made by Sámuel Kemény. Because one of his two sons died early, while the youngest never got married, the Klebelsberg Family became the owner of the castle in the 1890s [1, 2].

According to historical landowner surveys in 1896, Count William Klebelsberg's properties included 2,861 apple and 240 peach trees around the castle. Later on, the castle was owned by Melanie Georgina Antonia Josefa, also called "Baby Aunt," who owned the castle until 1949. After the Second World War, together with other similar castles, the Zichy Castle was also nationalized. After 1989, the legal owner retained it, and it actually serves as a cultural centre. The former Zichy Castle, as a double-deck building, was built by the former coast of the Maros River. The approximately 68-meter-long building is a beautiful example of the late $18^{\text {th }}$-century Transylvanian baroque (Fig. 1) [2, 3].

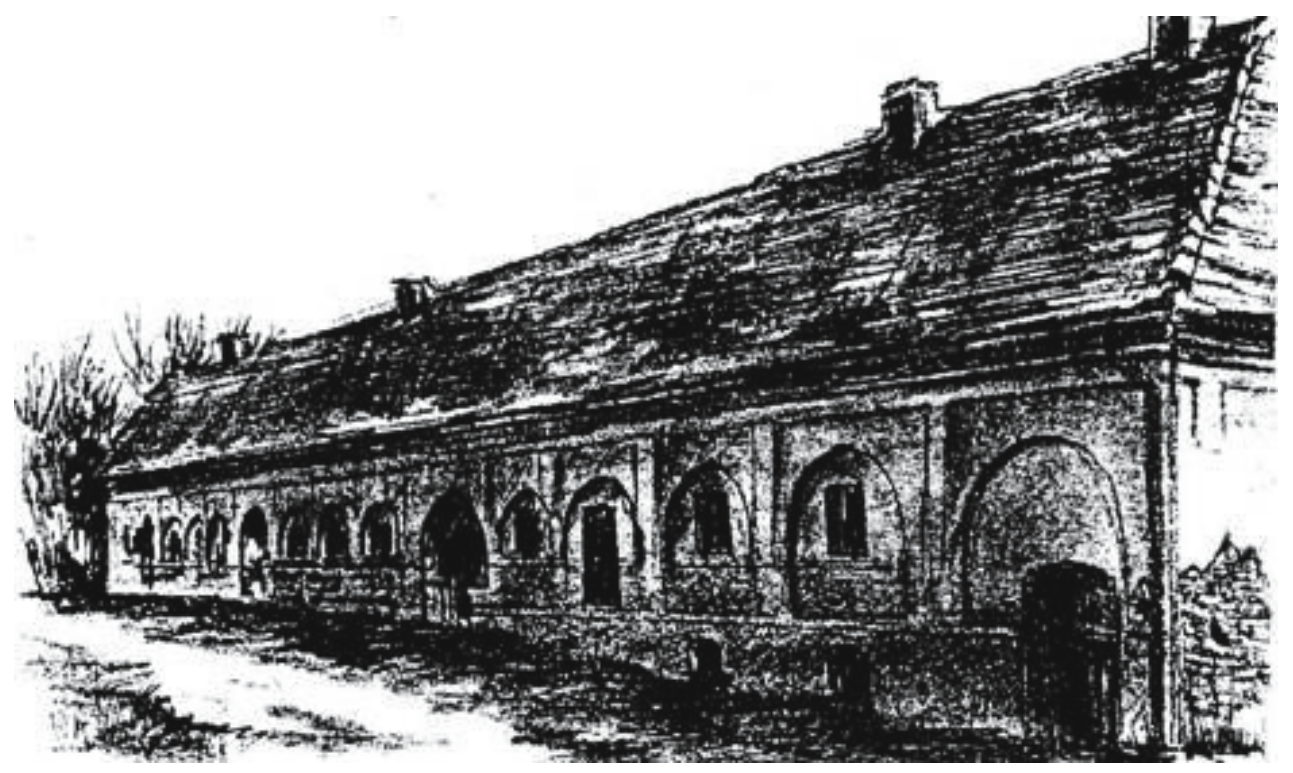

Fig. 1. The castle (By P. Zoltán) 
After the nationalization of the former court, the whole surroundings have been altered, partly being used as farm directory building but also as ethnographic museum and warehouses (Fig. 2). Almost no official documents have remained on the castle and its garden, but a description of the former park has survived as part of the personal stories and written memoires of Jozefa "Baby Aunt" [1, 2, 3].

"In the first half of the $20^{\text {th }}$ century, the castle garden, unlike the more similar gardens, was not a park. We simply called it garden. The estate itself was very extensive. That is why the properties of János Horváth and the Budai family were also owned by the Zichy Family. The inner squares were decorated by quadratic groups of red roses and pink geraniums. The evergreens were lined around the hedges. The garden did not have a built road, a dirt road between the buildings served as a connection. A grow was between Luc Creek and the River Maros. No typical garden elements were found in the garden. It had however a small lake and several water sources. The estate included a tennis court too. It was located on the north-eastern part of the main building."

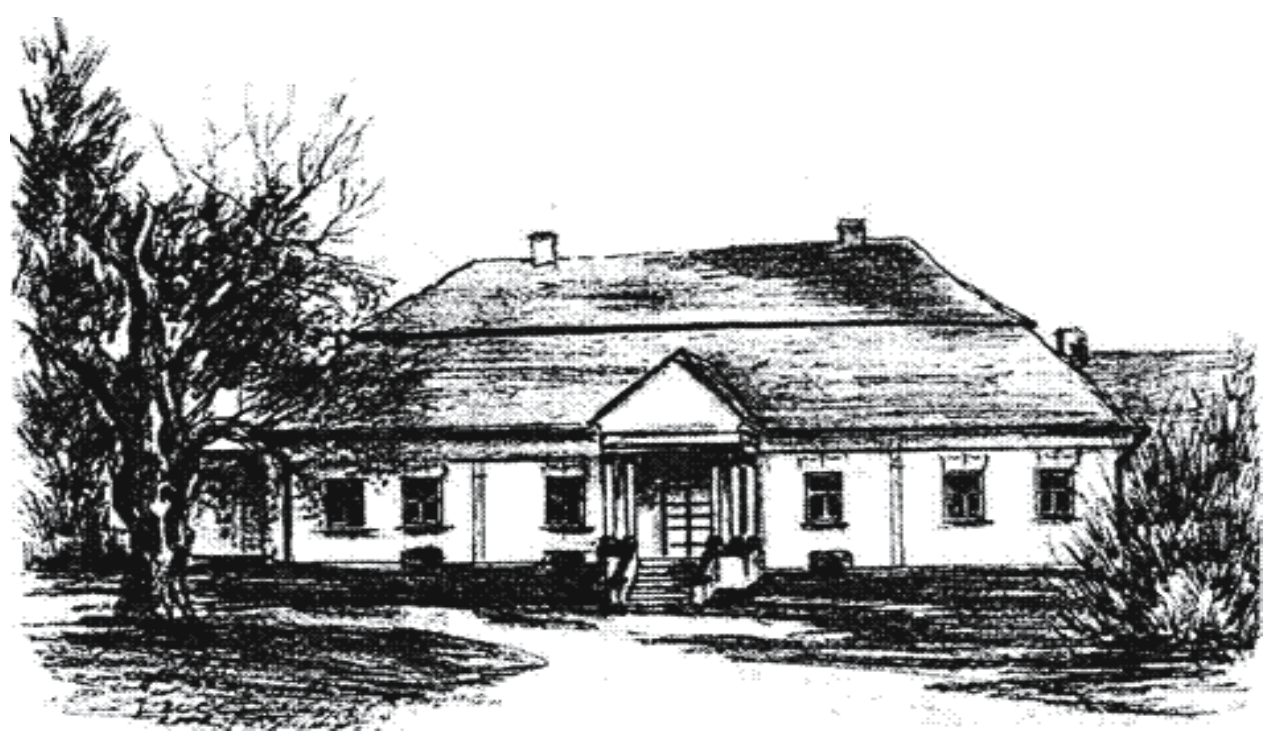

Fig. 2. The façade of the castle (by P. Zoltán) 


\section{The actual condition of the castle}

The main building is in a satisfactory stage; it has been recently renovated and equipped, serving as a cultural centre. The condition of the secondary building is critical, the roof structure is damaged. The old garden boundaries cannot be defined; so, no accurate assessment can be made about the former extent. The old garden elements can only be concluded from military maps and the geographical contours of the surrounding habitats. The place of the old lake can be identified. A complete change in plant compositions and structure is also clear; several old trees have been chopped down and several walnut trees planted. Major changes are also obvious if we compare the memoirs and old documents with the actual stages (Fig. $3)[4,5,6]$. The view of the two churches from the village is probably the only remaining aesthetical image, as several new buildings break the view and create "visual conflicts".

Together with several other old Hungarian noble castles from this area, this castle represents one of the examples of the Transylvanian baroque style that has become an important and even historical element of the Transylvanian environment $[4,5,6]$.

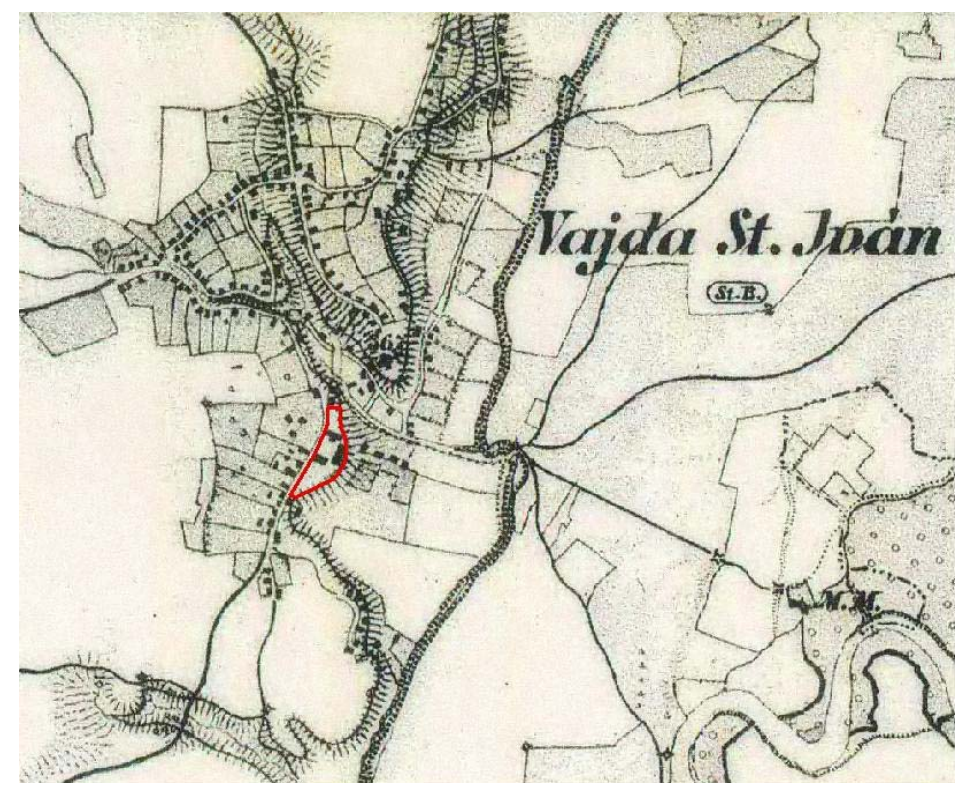

Fig. 3. The II. A map of military survey 


\section{References}

[1] Nagy, M. (1973), Várak, kastélyok, udvarházak, ahogy a régiek látták, Bukarest, Kriterion Könyvkiadó.

[2] Keresztes, Gy. (1995), Maros megyei kastélyok és udvarházak, Marosvásárhely, Impress Kiadó.

[3] Koppány, T. (1999), A középkori Magyarország kastélyai, Budapest, Akadémia Kiadó.

[4] Fekete, A. (2007), Az erdélyi kertművészet, Maros menti kastélykertek, Kolozsvár, Müvelődés Mühely.

[5] Kulcsár, Á. (1989), A gernyeszegi kastély Teleki Mihály kancellár korában és inventáriuma 1685-böl. In: Mủvészettörténeti Értesítő.

[6] Marosi, I. (1999), Örökbe hagyott beszélgetés Gróf Teleki Mihállyal, Budapest, Argumentum. 